\title{
Agriculture Education through Online Tools and Techniques amid COVID-19 Pandemic in India
}

\author{
Vivek Badhe $^{1 *}$, Deepak Kumar Namdeo ${ }^{1}$, A. S. Lodhi ${ }^{1}$ and \\ Dharmendra Singh Narwaria ${ }^{2}$ \\ ${ }^{1}$ College of Agriculture, Balaghat, India \\ ${ }^{2}$ College of Agriculture, Jabalpur, India \\ *Corresponding author
}

\section{A B S T R A C T}

Keywords

Lockdown,

Pandemic, COVID-

19, e-Resource,

Online tools

Article Info

Accepted:

10 January 2021

Available Online:

10 February 2021
The pandemic due to novel corona virus (COVID-19) has brought the whole world to a standstill. Mostly referred to as "Lockdown", has proposed that entire world should accept Work from Home as the next big change in work culture, and education system is not the exception one. The consequences of COIVD-19 are still affecting the educational system in India from pre-school to post-graduate studies. This paper presents the analysis carried out during this period, with the assistance of faculty members of agriculture education in India, about their experiences of online teaching and learning process. This study focuses on the effectiveness of available online tools in teaching methodology observed by faculty members, satisfaction level of teachers and of their students, the problems associated with it on either side, or its benefits as a learner, a teacher or an academic administrator. This paper also draws conclusions roughly on online tools, medium, platform, e-resources preferred by faculty members and a holistic view of the "new normal" scenario of Indian agricultural education system and its future.

\section{Introduction}

We all have witnessed the global lockdown and subsequent effects of it on each and every parts of our daily life due to COVID-19. The Online education which once was a periphery of primary to higher education now becomes a necessity. The education technology explores in a manner no one could imagine, whether it may be fashionable or desirable now in main stream. It is a whole new world for children growing up during this pandemic (Sahu, 2020). Lockdown confiding indoors most of us turning to virtual world, schools, colleges and universities are shut and move towards online teaching. Most cities converted their classes in clouds, usually collaborating with others and classrooms look like the screen of 
desktop or laptop. Not only students need to prepare themselves for this new mode of learning but entire educational system from faculty to management and government administration too. Each of us is challenged with new problems which was not part of our usual regular life. In one way, where this shifting paradigm of teaching creates new horizon for the learning, it creates the problem in other way where agriculture education which mostly based on the practical and fieldbased teaching suffers a lot. One interesting data is that before March 2020 only few percent in the world were learning online and after it more than expected has moved towards online teaching and learning (Lokanath Mishra et al., 2020). This was a mass mobilization of technology as per edx, an online education leader, observed record growth that they observed during this pandemic lockdown (edx Impact-Report, 2020.). Another global leader in online education Coursera observed high increase (Coursera-Impact-Report, 2020). BYJU's has observed a $200 \%$ boost in the number of new learner using its product (weforum.org, 2020). In spite of many government initiatives like Bharat Padhe Online, Swayam etc. of government of India, it is very demanding to bring the learners under the same platform in equal manner where several challenges of basic infrastructure development is in its midstream and technology reach is awaited (MHRD GOI Press Release, 2020).

\section{Online education scenario in India}

Ministry of Education, Government of India already took many important initiatives to promote e-learning and digital education in the nation through various e-platforms. Some of the high-quality initiatives like Digital India Initiative, National Programme on Technology Enhanced Learning abbreviated as NPTEL, Study Webs of Active Learning for Young Aspiring Minds well known as SWAYAM have many worth Massive Online Open Courses (MOOCs). The learner can enrol them and earn the knowledge and obtain certificate, diploma or degree in their respective fields. The major achievement of Ministry of Education, Government of India in satellite education is SWAYAM PRABHA. It is a gathering of 34 DTH channels. This program is committed to broadcasting of top notch instructive projects nonstop with the satellite GSAT-15. The contents are given by notable Higher Educational Institutions like IITs, NPTEL, UGC, CEC, IGNOU, NCERT, NIOS and eminent HEIs. The INFLIBNET Centre keeps up its own committed web-based interface. Every single day, there will be new substance in any event every 4 hours which would be rehashed 5 additional occasions in a day, permitting the understudies to pick the hour of their choice. Here is some analysis present regarding brighter and darker sides of online teaching learning in Indian education system set-up. The listed programmes are gained more attention during this pandemic period and peoples have realized the importance of these platforms (MHRD GOI Press Release, 2020 \& AISHE, 2019).

\section{Online Education as Rewards}

Online teaching and learning are seamless in urban areas where strong information communication technology infrastructure is available. The facility to learn from anywhere, anytime and many times is the key feature. The resource persons who are far from institution sometimes overseas can easily share their knowledge and impart in delivery of quality education. The services of multiple experts from different domain can be acquired in one place (Vidwan, 2020). Innovation and Technology makes online learning effortless business for younger generation and they have capability and enthusiasm for ease of adaptation in any difficult situation (Zhang et al., 2020). 


\section{Online education as restrictions}

Online education required basic infrastructure of information communication technology at user end, it is still a challenge in many parts in India and world as well. People don't have adequate experience of online teaching learning mechanism. Difficult to cope up with scenario where technological changes rapidly specially for the middle-aged and elderly teachers who are not tech-savvy. The most common and desirable feature is absence of peer learning, missing group contact, social interaction and face to face teaching learning. (Florian Klapproth et al.,2020).

\section{Policy and guidelines from regulatory}

All the academic institutions of the country have been closed for physical presence since 16th March, 2020 because the Government of India announced a countrywide lockdown to breakdown the chain of COVID-19. In this situation, academic institution found some challenges as well as new opportunities to continue academic activities. After the declaration of policy responses and recommendations by NESCO for HEIs at global level, Indian regulatory also releases their policy and advisory (UNESCO IESALC, 2020). The top most academic regulatory in the nation University Grant Commission (UGC) and Council of Agricultural Research (ICAR) provide the course of action for concerning academic activities The UGC issued guidelines on examinations and academic calendar for the universities in view of COVID-19 and subsequent lockdown on 29th April, 2020 and then, on 6th July, 2020.

These Guidelines covered important dimensions related to examinations, academic calendar, admissions, online teaching-learning and provided flexibility to universities. UGC issued guidelines for new academic session on 24th September 2020, where universities and colleges need to make a customized plan, as per the local conditions to deal with any eventuality arising due the COVID-19 before resuming activities on campuses (UGC, 2020).

In continuation to the UGC guidelines the agriculture education regulatory body ICAR issued the broad policy to all State Agricultural Universities, Central Agricultural Universities and other agricultural and allied institutions under the periphery of council.

The concern agricultural universities/institution develops their own standard operating procedure in light of the ICAR advisory regarding safety measures to novel corona virus (COVID-19) in order to implement online classes and conduct the final year student Rural Entrepreneurship Awareness Development Yojana (READY) programme with reschedule academic calendar for examination and evaluation and admission (ICAR, 2020).

\section{The new normal due to COVID-19}

Some of the focused area listed below mentioned in the guidelines and policy provided by regulatory bodies for agricultural education during lockdown and subsequent stages become the new normal for education system (Thammi-Raju et al., 2020).

Follow the norms of social distancing

Regular use of sanitizer and wearing mask

Online content delivery

Development of the standard operating procedures $(\mathrm{SoP})$ for academic activities

Online student counselling

Capacity building and moral boost up of faculty members 
Make the most of on the available capacity

Learner-centric teaching

Inclination for virtual teaching-learning

Shift towards technology driven education

National Education Policy 2020: Online Education

Education system in agriculture and its allied disciplines are going to be revitalized. Though Agricultural Universities comprise more or less $9 \%$ of all universities within the nation, enrolment in agriculture education and allied sciences is a smaller amount than $1 \%$ of all enrolment in higher education. Each quantity and quality of agriculture and allied disciplines should be improved so as to extend agricultural productivity through competent graduates, innovative research, and marketbased extension joined to technologies and practices. The preparation of execs in agriculture and veterinary sciences through programs integrated with general education can be exaggerated sharply. The aspect of agricultural education will shift towards developing professionals with the ability to grasp and use native knowledge, ancient knowledge, and rising technologies whereas being cognizant of crucial problems, cherish declining land productivity, climate change, food sufficiency for our growing population, and so on. Establishments providing agricultural education should profit the local people directly. One approach may be to line up Agricultural Technology Parks to push technology incubation and propagation and encourage property methodologies.

National education policy 2020 of India focused on the use of Information Communication Technology in education to cope up with new circumstances and realities rise in epidemics and pandemics. Traditional and in-person modes of education are not possible in the age of COVID-19 therefore, digital modes of education and learning are more popular. NEP 2020 concerned on effectiveness and quality of online and digital education from school to higher education. These are the key recommended in NEP 2020 for the effective implementation of online and digital education in India (National Education Policy, 2020).

Pilot studies for online education

Digital infrastructure

Online teaching platform and tools

Content creation, digital repository, and dissemination

Addressing the digital divide

Virtual Labs

Training and incentives for teachers

Online assessment and examinations

Blended models of learning

Laying down standards

\section{Materials and Methods}

The researcher utilized quantitative as well as qualitative methodologies to analyse the data collected from participants faculties of different state agricultural universities (SAUs) and central agricultural research and teaching institutions of pan India and covered 19 states or union territory as shown in figure-1, namely Andhra Pradesh (1), Bihar (23), Chhattisgarh (15), Goa (02), Haryana (02), Jharkhand (03), Karnataka (01), Kerala (04), Madhay Pradesh (146), Maharashtra (14), Odisha (01), Rajasthan (07), Sikkim (01), Tamil Nadu (03), 
Telangana (05), UT Of Jammu And Kashmir (02), Uttar Pradesh (09), Uttarakhand (06) and West Bengal (05). The data is collected during the lockdown period, in five-day online Faculty Development Programme (FDP) organized by College of Agriculture, Balaghat under Jawaharlal Nehru Agricultural University Jabalpur (M.P.)

India during $16^{\text {th }}-20^{\text {th }}$ May 2020. During the five-day FDP, we collected responses of 45 questionnaires from 250 participant faculties. The questionnaire is divided into five segments first segment demand the personal data of participants like name, age, designation, place etc. The second segment covers the feedback of the said programme.

Third segment dedicated to take responses towards online experience of participants during lockdown and in-general. The fourth segment took the opinion on online tools and platform and the last segment perform the survey on e-Resources utilization and related aspects.

\section{Results and Discussion}

This section presents the analysis of data collected from faculty members that belongs to different agricultural universities and states. One parameter which was difficult to quantify is the remarks and subjective opinion given by them is complied and can be summarised as "Though online mode of teaching is the need of hour and have many benefits, some part of education especially in practical part of agricultural education is almost impossible to deliver through online mode."

The final year Student READY (Rural Entrepreneurship Awareness Development Yojana) program which includes Rural Agricultural Work Experience (RAWE), Agro Industrial Attachment (AIA) and Experiential Learning Program (ELP) and some field based experiments need actual environment rather than virtual setting. In the lockdown period the online classes emerged as alternative to the class room teaching and almost $86.4 \%$ faculties are taking online classes, but the same time $72 \%$ faculties are not in favour of online off-campus examination or test as an evaluation tool. Almost 9\% faculties are in the perplexity of online class and test shown in figure-2.

As describe in figure-3, the different online platform and tools are used for online classes but the clear-cut winner is the Google Meet with $59.6 \%$ user utilize it's the services, and next subsequent popular platforms are Zoom and Cisco WebEx with $48.4 \%$ and $34.8 \%$ user base while almost $12.8 \%$ people uses other platforms for the online teaching and learning.

The figure-4, explain the preference of user regarding platform. From the above data, it is clear that user base of Google Meet is at the top, and at the same time it is in the priority with $63.2 \%$ users ranked as first choice and it is far ahead with second ranked Zoom with $20.8 \%$ and Cisco WebEx with $4.4 \%$ in the liking list.

Even though the online mode of teaching is the only viable option available during the crises period of lockdown, 54.8\% faculties have adapted this mode contentedly and find this mode comfortable and deliverable for teaching while the rest find abrasive and difficult, as figure- 5 indicates.

In the part of satisfaction level we observe shown in figure-6, a consistency that a good number of faculties are satisfied with online workshop and training, but as far as online class is concerned the satisfaction level of faculties and their students varies in different contentment band. Table-1 shows the satisfaction level of faculties and their students in different aspects. 
Table.1 Level of satisfaction for online classes

\begin{tabular}{|c|c|c|c|c|c|}
\hline Question/Particular & $\mathbf{4 5 0 \%}$ & $\begin{array}{c}\text { Between } \\
\mathbf{5 1 \% -} \\
\mathbf{7 5 \%}\end{array}$ & $\begin{array}{c}\text { Between } \\
\mathbf{7 6 \% -} \\
\mathbf{9 0 \%}\end{array}$ & $\mathbf{> 9 0 \%}$ & $\begin{array}{c}\text { No } \\
\text { Class }\end{array}$ \\
\hline $\begin{array}{c}\text { How much are you satisfied with } \\
\text { online classes? }\end{array}$ & 13 & 78 & 89 & 51 & 19 \\
\hline $\begin{array}{c}\text { How much are your students } \\
\text { satisfied with online classes? }\end{array}$ & 18 & 86 & 75 & 44 & 27 \\
\hline $\begin{array}{c}\text { How much are you satisfied with } \\
\text { online training / workshops? }\end{array}$ & 5 & 52 & 96 & 97 & 0 \\
\hline
\end{tabular}

Table.2 E-Resources utilization in PAN India

\begin{tabular}{|c|c|c|c|c|c|c|c|c|c|c|}
\hline \multirow[t]{2}{*}{ State } & \multirow[t]{2}{*}{$\begin{array}{l}\text { Participa } \\
\text { nts }\end{array}$} & \multicolumn{3}{|c|}{$\begin{array}{c}\text { Do you use } \\
\text { E-resources? }\end{array}$} & \multicolumn{3}{|c|}{$\begin{array}{c}\text { Are online e-resources } \\
\text { satisfied your } \\
\text { information need } \\
\text { during COVID-19 } \\
\text { period? }\end{array}$} & \multicolumn{3}{|c|}{$\begin{array}{l}\text { Do you use mobile } \\
\text { apps to access or } \\
\text { searching e- } \\
\text { resources }\end{array}$} \\
\hline & & Yes & $\begin{array}{l}\text { May } \\
\text { be }\end{array}$ & No & Yes & $\begin{array}{l}\text { May } \\
\text { be }\end{array}$ & No & Yes & $\begin{array}{l}\text { May } \\
\text { be }\end{array}$ & No \\
\hline $\begin{array}{l}\text { ANDHRA } \\
\text { PRADESH }\end{array}$ & 1 & 1 & & & 1 & & & 1 & & \\
\hline Bihar & 23 & 21 & 2 & & 21 & 2 & & 19 & & 4 \\
\hline Chhattisgarh & 15 & 15 & & & 15 & & & 12 & & 3 \\
\hline Goa & 2 & 2 & & & 2 & & & 2 & & \\
\hline Haryana & 2 & 2 & & & 0 & 2 & & 0 & 2 & \\
\hline $\begin{array}{c}\text { Jammu \& } \\
\text { Kashmir }\end{array}$ & 2 & 2 & & & 1 & 1 & & 2 & & \\
\hline Jharkhand & 3 & 3 & & & 3 & & & 3 & & \\
\hline Karnataka & 1 & 1 & & & 1 & & & 1 & & \\
\hline Kerala & 4 & 4 & & & 2 & 1 & 1 & 2 & & 2 \\
\hline Madhya Pradesh & 146 & 138 & 7 & 1 & 134 & 12 & & 125 & 8 & 13 \\
\hline Maharashtra & 14 & 12 & 1 & 1 & 13 & 1 & & 14 & & \\
\hline Odisha & 1 & 1 & & & 1 & & & 1 & & \\
\hline Rajasthan & 7 & 7 & & & 5 & 1 & 1 & 6 & & 1 \\
\hline SIKKIM & 1 & 1 & & & 1 & & & 1 & & \\
\hline Tamil Nadu & 3 & 3 & & & 3 & & & 3 & & \\
\hline Telangana & 5 & 4 & & 1 & 5 & & & 4 & & 1 \\
\hline Uttar Pradesh & 9 & 9 & & & 8 & 1 & & 5 & 2 & 2 \\
\hline Uttarakhand & 6 & 6 & & & 5 & 1 & & 4 & 1 & 1 \\
\hline West Bengal & 5 & 5 & & & 5 & & & 4 & 1 & \\
\hline & 250 & 237 & 10 & 3 & 226 & 22 & 2 & 209 & 14 & 27 \\
\hline
\end{tabular}


Table.3 Satisfaction level of e-Resource

\begin{tabular}{|c|c|c|c|}
\hline Question Related to E-Resources & \multicolumn{3}{|c|}{$\begin{array}{c}\text { Response Received } \\
\text { (out of 250) }\end{array}$} \\
\cline { 2 - 4 } & Yes & May be & No \\
\hline Do you use e-resources? & 237 & 10 & 3 \\
& $(94.8 \%)$ & $(4 \%)$ & $(1.2 \%)$ \\
\hline $\begin{array}{c}\text { Are online e-resources satisfied your } \\
\text { information need during COVID-19 period? }\end{array}$ & $\begin{array}{c}226 \\
(90.4 \%)\end{array}$ & $\begin{array}{c}22 \\
(8.8 \%)\end{array}$ & $\begin{array}{c}(0.8 \%) \\
\text { Do you use mobile apps to access or } \\
\text { searching e-resources? }\end{array}$ \\
\hline & 209 & 14 & \\
\hline & $(88.6 \%)$ & $(5.6 \%)$ & $(10.8 \%)$ \\
\hline
\end{tabular}

Fig.1 PAN India coverage of participants

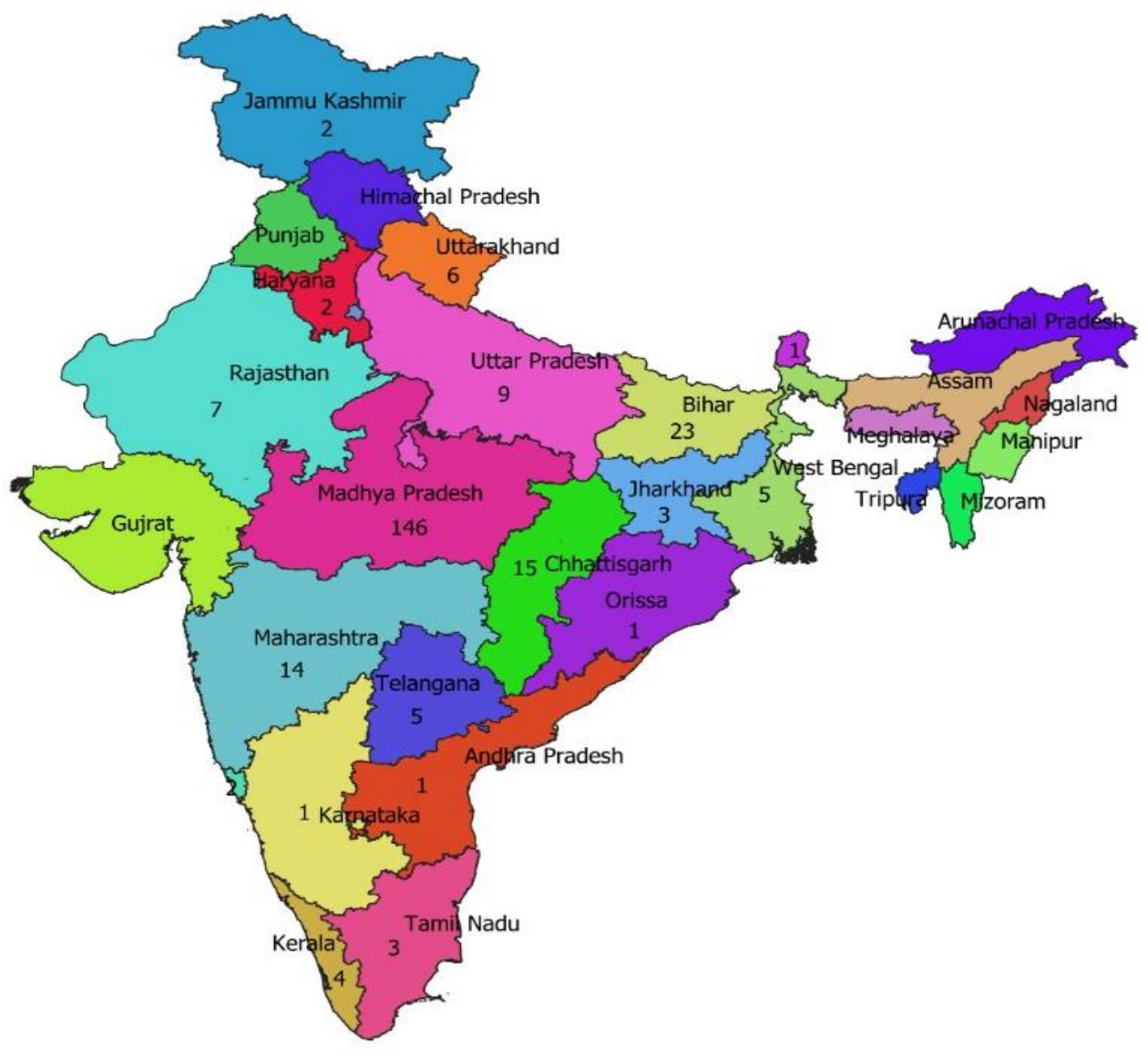


Fig.2 Online class and test scenario

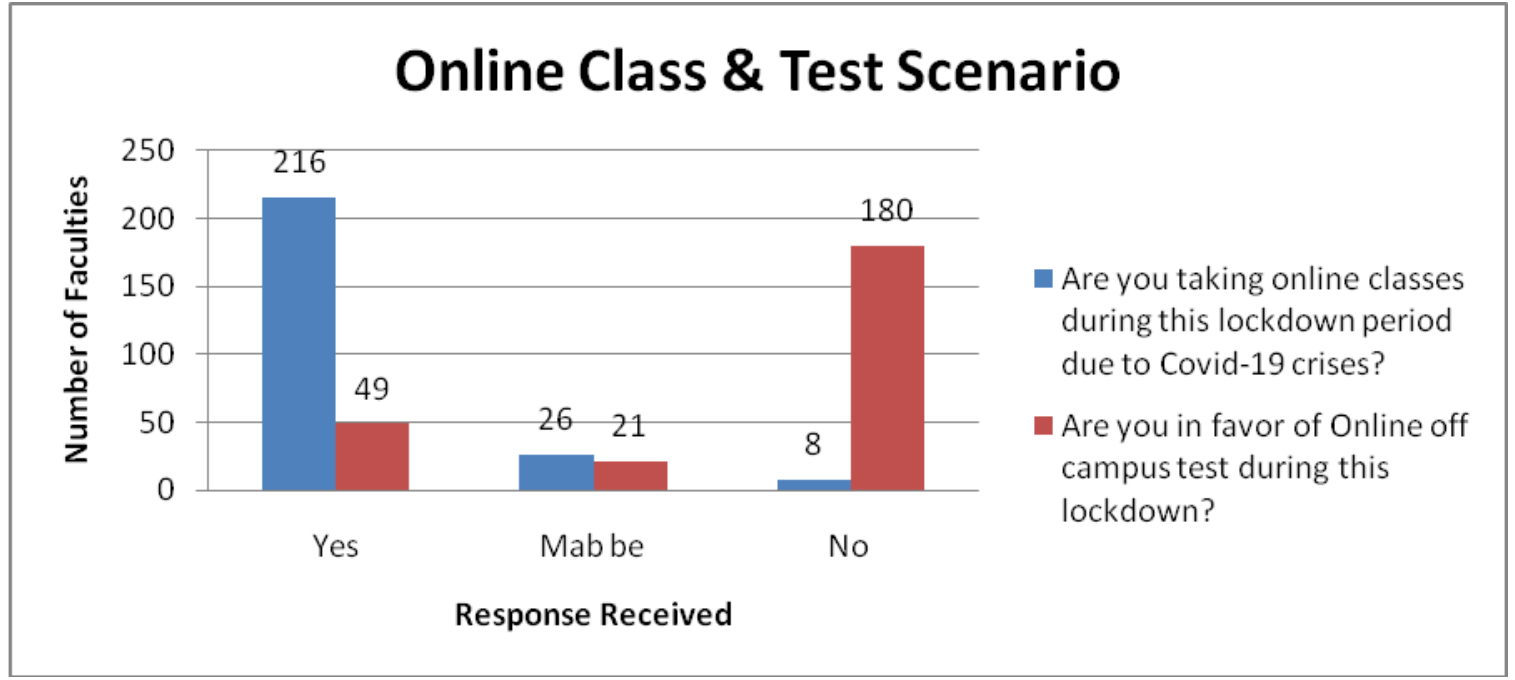

Fig.3 Online platform user base

\section{Which platform you are using to take online classes/ Meeting?}

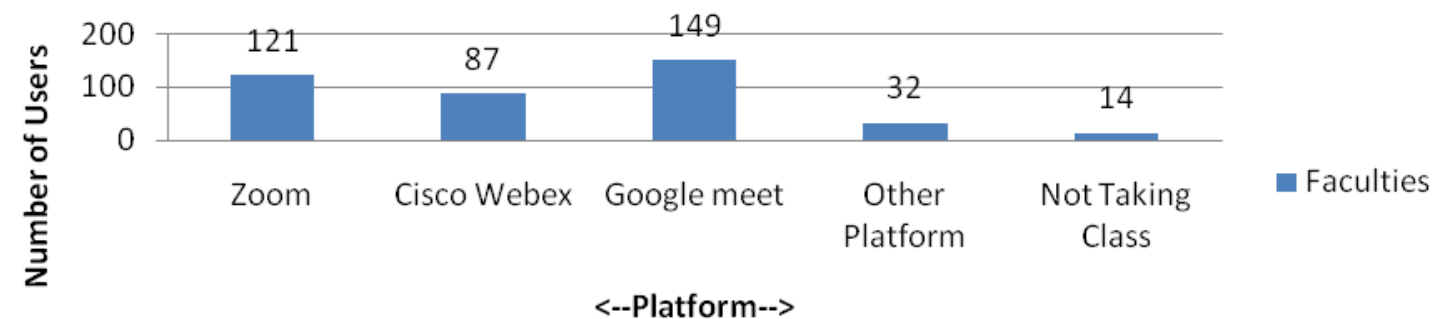

Fig.4 Online platform user preference

\section{Online Platform User Preference \%}

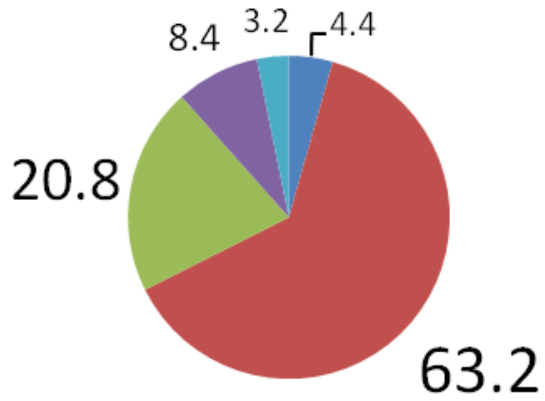

Cisco Webex

Google Meet

Zoom 


\section{Which mode of teaching is the easiest and most comfortable way for you to teach?}

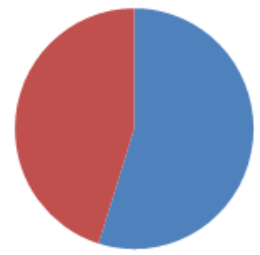

Online \%

- Offline \%

Fig.6 Online class satisfaction

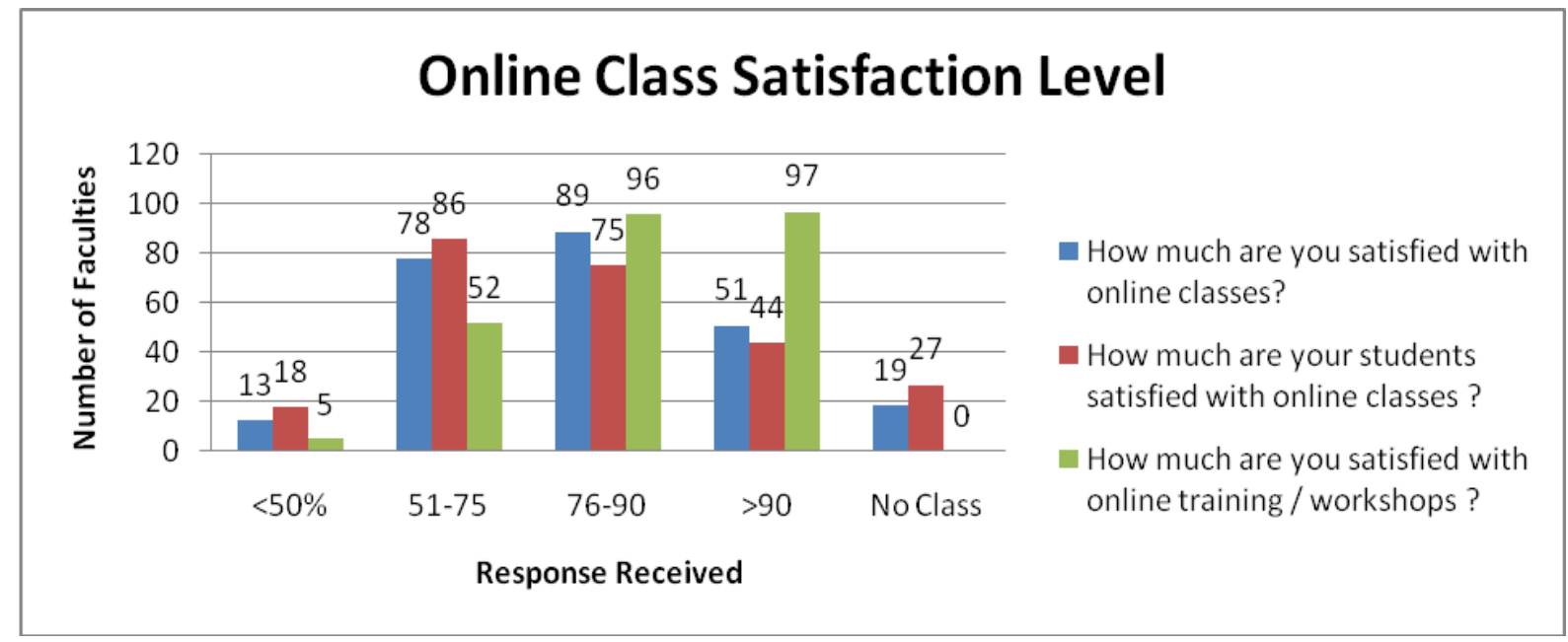

Fig.7 Online class frequency

\section{User Percentage Classes Taken Per Day}

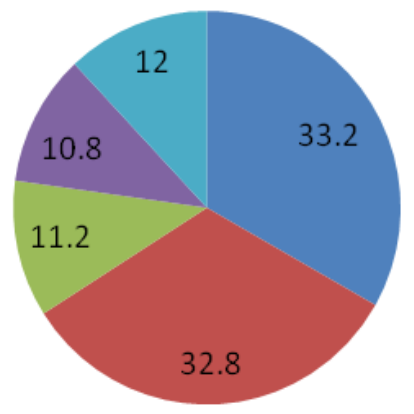

1 Class

2 Classes

3 Classes

$4+$ Classes

No Class 
Fig.8 E-Resource utilization

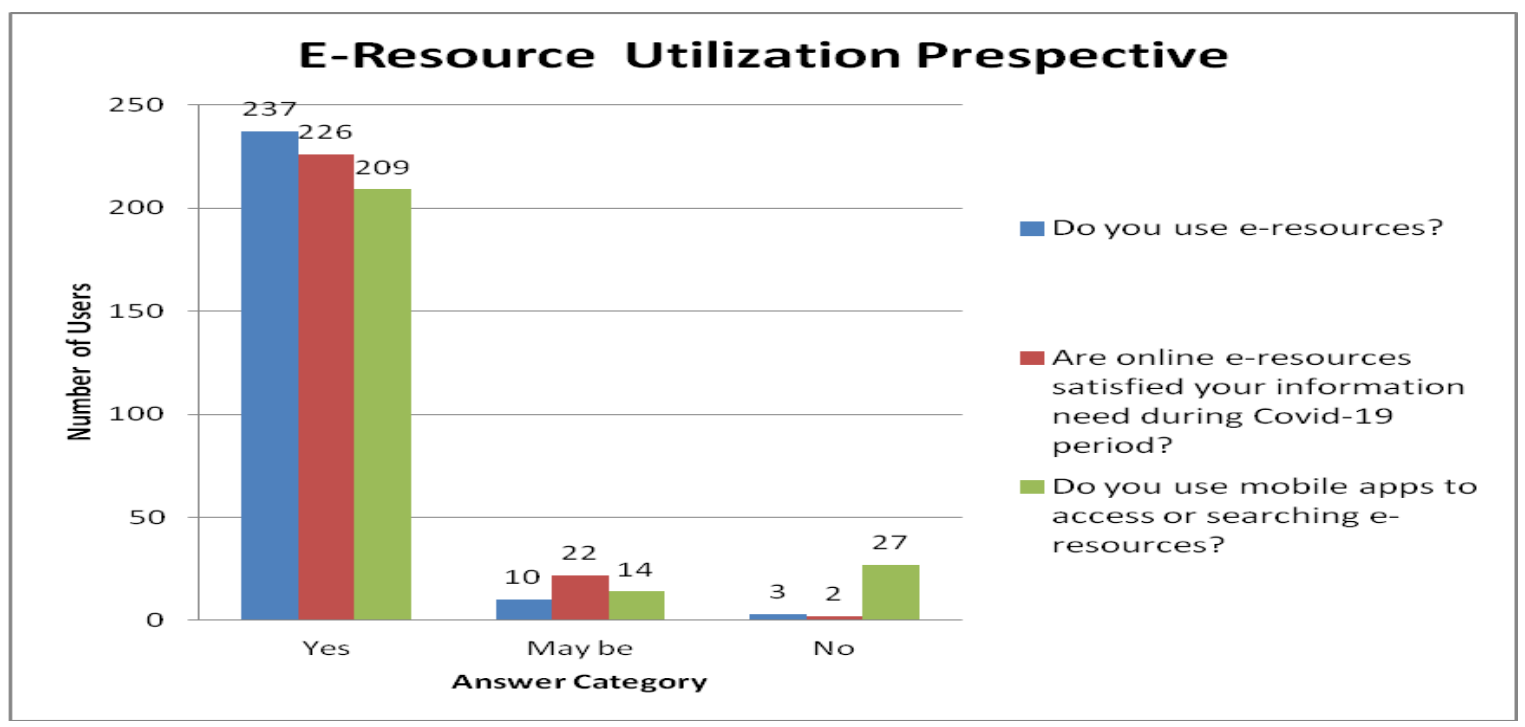

One of the key observations was that online classes for short duration and lesser class is more popular than the long duration and more classes. The faculties percentage is $33.2 \%$ who took one class per day, $32.8 \%$ who took two classes per day, $11.2 \%$ who took three classes per day and $10.8 \%$ who took 4 or more classes per day while $12 \%$ faculties are not involved in online teaching indicates in figure-7.

Table-2 and Table-3 shows during COVID-19 pandemic, $94.8 \%$ participants have used eresources and $90.4 \%$ said that e-resources fulfilled their information need. Only $1.2 \%$ participates did not use e-resources and information need of $0.8 \%$ participants are not satisfied with e-resources. $83.6 \%$ participants use mobile app to find and access the eresources hence during lockdown use of mobile app increased. The Figure-8 indicates that majority of the participants were using eresources and it satisfied the need of learners and only few numbers of participants did not utilized the e-resources.

When teacher and students are in same physical place the relationship between them is phenomenal. It results better transformation of knowledge. The Online mechanism doesn't have social interaction and face to face presence, though it is a good alternative because it ensures and enables learner to allow learn from anywhere, learn any time, and many times, but it is not something to be a replacement of traditional mode of teaching. Instead, the new emerging trend called blended mode of learning, which is mixed (as per requirement) of offline traditional teaching-learning mode and modern as well as contemporary online learning approach. It has gained more and more popularity to have become the future of agricultural and other educational systems, and finally one can say the blended become a new normal for educational system in the country.

\section{Compliance with ethical standards}

The authors declare that they have no conflict of interests.

\section{Acknowledgement}

The authors thank all participating teaching faculty and research scholars' of all SAU across national and Central Agriculture Educational agencies who participated in online faculty development programme and 
sharing their valuable experience and information with us.

\section{Funding}

This research did not receive any specific grant from funding agencies in the government, public, private-industry or nonprofit sectors.

\section{References}

Sahu, P. (2020). Closure of universities due to coronavirus disease 2019 (COVID19): Impact on education and mental health of students and academic staff. Cureus, 12 (4), 1-6. 10.7759/cureus.7541.

Lokanath Mishra, Tushar Gupta, Abha Shree, "Online teaching-learning in higher education during lockdown period of COVID-19 pandemic", International Journal of Educational Research Open Published by Elsevier Ltd. (2020)

https://about.coursera.org/press/wpcontent/uploads/2020/09/CourseraImpact-Report-2020.pdf

https://www.edx.org/assets/2020-impactreport-en.pdf

https://www.weforum.org/agenda/2020/04/cor onavirus-education-global-covid19online-digital-learning/

Ministry of Human Resource Development, GOI Press Release (2020). Available at:

https://pib.gov.in/PressReleasePage.as px?PRID=1624868.

All India Survey on Higher Education (AISHE). (2019). Ministry of Human Resource Development. New Delhi: Government of India.

Vidwan - Expert Database and National Researcher Network (2020). Available at:https://vidwan.inflibnet.ac.in/.

Zhang, W., Wang, Y., Yang, L., \& Wang, C. (2020). Suspending classes without stopping learning: China's education emergency management policy in the COVID-19 outbreak. Journal of Risk and Financial Management, 13 (55), 2-6. 10.3390/jrfm13030055.

Florian Klapproth, Lisa Federkeil,Franziska Heinschke and Tanja Jungmann Teachers' experiences of stress and their coping strategies during COVID19 induced distance teaching, Journal of Pedagogical Research Volume 4, Issue $\quad 4, \quad 2020$ http://dx.doi.org/10.33902/JPR.202006 2805

UNESCO IESALC (2020). COVID-19 and higher education: Today and tomorrow. Impact analysis, policy responses and recommendations. Retrieved from http://www.iesalc.unesco.org/en/wpcontent/uploads/2020/04/COVID-19EN- 090420-2.pdf.

UGC (2020, April). Report of the UGC committee on examinations and academic calendar for the universities in view of COVID-19 pandemic and subsequent lockdown. Retrieved from https://www.ugc.ac.in/pdfnews/427644 6_UGC-Guidelines-on-Examinationsand- Academic-Calendar.pdf.

ICAR Advisories to Agricultural Universities during COVID-19 pandemic (2020). Available at: https://icar.org.in/content/advisoriesagricultural-universities-during-covid19-pandemic.

Thammi-Raju, D., Ramesh, P., Krishnan, P., Soam, SK., Srinivasarao, Ch., Agrawal, RC. 2020. Re-imagining Higher Agricultural Education in India on the Face of Challenge from COVID-19 Pandemic - Strategies for Adapting to the New Normal. ICAR Policy Paper, Indian Council of Agricultural Research (ICAR), New Delhi, p14. 
Draft National Education Policy (2020) of Government of India. Available at: https://www.education.gov.in/sites/upl
oad_files/mhrd/files/NEP_Final_Engli sh_0.pdf

\section{How to cite this article:}

Vivek Badhe, Deepak Kumar Namdeo, A. S. Lodhi and Dharmendra Singh Narwaria. 2021. Agriculture Education through Online Tools and Techniques amid COVID-19 Pandemic in India. Int.J.Curr.Microbiol.App.Sci. 10(02): 1219-1230.

doi: https://doi.org/10.20546/ijcmas.2021.1002.143 